\title{
ע Ammattientarkastaja Vera Hjelt ja ravitsemusvalistus osana työsuojelua
}

\begin{abstract}
Teollisuustyöväestä tuli 1800-luvun lopun Suomessa ensimmäinen suuri väestöryhmä, jonka elämässä työ irtaantui kodin piiristä tehtaisiin ja verstaisiin. Se vaikutti monien muiden seikkojen lisäksi ruokailutottumuksiin. Tässä artikkelissa tarkastellaan Suomen ensimmäisen naispuolisen ammattientarkastajan, Vera Hjeltin, toimintaa työväestön ravitsemukseen ja työaikaiseen ruokailuun liittyvissä kysymyksissä. Hjelt oli kiinnostunut valistustyöstä ja hänen tavoitteenaan oli etenkin naisten työolojen parantaminen. Hjeltin käytännöllinen lähestymistapa ravitsemuskysymyksiin näkyi myös hänen 1909 perustamassaan työsuojelunäyttelyssä. Hänen lähes kolmekymmentä vuotta kestänyt toimintansa työväestön työ- ja elinolojen parantamiseksi on merkittävä osa suomalaisen ravitsemusvalistuksen historiaa. Vera Hjeltiä voidaan pitää myös työpaikkaruokailun kehittämisen uranuurtajana Suomessa.
\end{abstract}

\section{ASIASANAT: Vera Hjelt, ravitsemusvalistus, työaikainen ruokailu, ruokakulttuuri, työväestö}

KAIJA RAUTAVIRTA

\section{JOHDANTO}

Vera Hjelt (1857-1947) oli koulutukseltaan kansakoulun- ja veistonopettaja. Hän toimi opettajana, saha- ja veistotehtaanjohtajana, ammattientarkastajana, kansanedustajana ja työsuojelumuseon johtajana. Hänen monipuolista yhteiskunnallista toimintaansa on kuvattu elämäkertakirjoituksissa (1-3), ja hänen työhönsä ja tutkimuksiinsa on viitattu lukuisissa työsuojelua, työläisnaisten asemaa sekä kulutusta käsittelevissä julkaisuissa.

Vuosina 1903-1917 Hjelt toimi teollisuushallituksen ammattientarkastajana, jossa tehtävässä hän perehtyi naistyöväen työ- ja asuinoloihin. Vuonna 1909 hän perusti ulkomaisten esimerkkien innoittamana Helsinkiin työsuojelua esittelevän ja valistavan näyttelyn, jonka johtajana hän oli vuoteen 1931. (3) Työväestön ravintoon liittyvät kysymykset sisältyivät alusta lähtien näyttelyn teemoihin.

Tarkastelen tässä artikkelissa Vera Hjeltin toimintaa kansanravitsemuksen näkökulmasta ja peilaan sitä ajankohdan keskeisiin ravitsemuskysymyksiin. Tuon esiin niitä seikkoja, joihin
Hjelt kiinnitti huomiota sekä niitä toimia, joita hän käynnisti työaikaisen ruokailun kehittämiseksi ja työväestön ravitsemuksen kohentamiseksi. Tarkasteltavana on lähes kolmenkymmenen vuoden ajanjakso.

Työväestön ruokaolot olivat vain osa Hjeltin työnkuvaa, ja monet ammattientarkastajalle kuuluneet tehtävät jäävät tässä vaille huomiota. Valinta on kuitenkin perusteltu, sillä Vera Hjeltin roolia "ravitsemusvalistajana" ja työaikaisen ruokailun kehittäjänä ei ole aiemmin yksityiskohtaisesti käsitelty. Hän oli ensimmäisenä naisammattientarkastajana edelläkävijä, joka loi perustan toiminnalle ja tavalle kehittää työväestön ruokaoloja.

Rakennan kuvaa Vera Hjeltin toiminnasta erityyppisten lähteiden avulla. Yleiskuva Hjeltin vaiheista perustuu elämäkertatietoihin. (1-3) Ensisijaisina lähteinä ovat olleet hänen ammattientarkastajan tehtävässä toimittamansa vuosikertomukset vuosilta 1903-1915 (4). Osan aineistoa muodostavat ne yksittäiset tutkimukset työntekijöiden ammattioloista ja toimeentulosta, jotka 
Hjelt laati ammattientarkastajan tehtävän ohessa. $(5,6)$ Kuvaa Vera Hjeltin toiminnasta täydentää työsuojelunäyttelyä koskeva aineisto. Se koostuu arkisto-aineistosta, kuten näyttelyesineluetteloista, sekä vuosikertomuksista. (7) Lisäksi aineistoa ovat olleet aihepiiriin liittyvät yksittäiset lehtiartikkelit.

\section{TYÖSUOJELULLE PUITTEET}

Vilkas teollistuminen 1800-1900-lukujen vaihteessa synnytti Suomeen uusia työpaikkoja ja osaltaan vaikutti muuttoliikkeen voimistumiseen maaseudulta kaupunkeihin ja taajamiin. Kaupunkilaisväestön osuus kasvoi 1860-luvun kuudesta prosentista noin 20 prosenttiin 1910-luvun puoliväliin mennessä. (8) Enemmistö maalta muuttaneista oli naisia, ja heidän osuutensa työvoimasta oli vuosisadan alussa korkea. (9) Huomattava naisten tehdastyön keskus oli Tampere, jossa naisten osuus tehdastyöläisistä oli esimerkiksi vuonna 1900 noin 53 prosenttia. (10) Naiset työskentelivät useilla aloilla, kuten kutoma-, paperi-, rulla-, lasi-, tulitikku- ja tupakkatehtaissa, puuhiomoissa, kirjansitomoissa ja kirjapainoissa, elintarvikeja vaatetusteollisuudessa sekä suurilla sahalaitoksilla. (4)

Teollistuminen toi työsuhteisiin varmuutta, mutta pitkät työpäivät, puutteellinen työopastus ja kehnot työolot synnyttivät vaaratilanteita ja aiheuttivat terveysongelmia. Suomalaisen työsuojelun katsotaan alkaneen 1889 , jolloin annettiin asetus teollisuusammateissa toimivien työntekijöiden suojelusta. $(3,11)$ Asetuksen valvomiseksi teollisuushallitukseen nimettiin kaksi miespuolista ammattientarkastajaa. Muutama vuosi myöhemmin perustettiin naispuolisen ammattientarkastajan virka. Naisen arveltiin ymmärtävän miehiä paremmin naisten ja lasten oloja, ja naistyöntekijöiden ajateltiin puolestaan uskoutuvan mieluummin nais- kuin miespuoliselle tarkastajalle. $(3,12)$ Johtosäännön mukaan naispuolisen ammattientarkastajan tuli valvoa "työntekijöiden siveellisiä ja terveydellisiä oloja, vaikuttaa kansa- ja ammattikoulujen säännölliseen käyttämiseen sekä naispuolisten työntekijäin asunto- ja ravinto-olojen parantamiseen, niin myös koettaa aikaansaada teollisuusammattien työntekijöitä varten aiottuja terveydenhoito- ja sairashoitosekä ruoanpitolaitoksia kuin myöskin apu- ja säästökassoja”. (13)
Aloitteellinen viran perustamisessa oli Suomen Naisyhdistys (per. 1884). Tiedossa oli, että 1893 Englannissa perustettu vastaava toimi oli osoittautunut yhteiskunnallisesti tärkeäksi. Naisyhdistyksen Koti ja yhteiskunta -lehdessä käsiteltiin naisammattientarkastajan tehtäviä ja niistä tärkeimpänä pidettiin työväestön asunto- ja ruokaolojen parantamista. $(1,14)$ Naisyhdistyksen puheenjohtaja Aleksandra Gripenberg ajoi Vera Hjeltin nimittämistä tehtävään. Hän sai kannatusta myös teollisuushallituksen ja miespuolisten ammattientarkastajien taholta. (1) Hjeltillä katsottiin olevan alaan soveltuva koulutus ja kokemusta teollisuustyöstä. (3)

Tehtävän sijoituspaikka oli Helsinki, mutta toimialueena oli koko Suomi. Sen lisäksi, että Hjelt teki vuosittain lukuisia tarkastusmatkoja tehdaslaitoksiin, hän vieraili työläisperheissä tutustuakseen heidän asunto-oloihinsa. Vuonna 1909 Suomi jaettiin kahteen naisammattientarkastajan piiriin, ja Vera Hjeltin vastuulle tulivat Helsingin, Tampereen ja Oulun piirit. $(3,4)^{1}$

Työsuojelullisten kysymysten lisäksi ajankohta herätti kiinnostuksen suomalaiseen kansanravitsemustutkimukseen. Aloitteen teki syksyllä 1903 Helsingin yliopiston fysiologian professori Robert Tigerstedt, joka korosti työväestöön kohdistuvan ruoankäyttötutkimuksen tärkeyttä. Siten saataisiin uutta tietoa suomalaisväestössä yleisesti esiintyvien ruoansulatuskanavan sairauksien hoitoon, väestön valistamiseen, työtehon arviointiin ja laitosruokailun järjestämiseen. Uuden tiedon myötä ruokailua oli mahdollista muuttaa terveellisemmäksi ilman, että se samalla kallistuisi. (15) Sittemmin Tigerstedtin aloite johti useisiin väestön ravinnonsaannin riittävyyttä selvittäneisiin tutkimuksiin. $(16)^{2}$

\section{KAUPUNKITYÖVÄESTÖN RUOKAMAAILMA}

Suomalaisten ruokatottumukset, ateriat ja niiden rytmi, pysyivät lähes muuttumattomina 1800 -luvun lopulle asti. (17) Maatalousyhteiskunnassa

\footnotetext{
${ }^{1}$ Toiseksi naispuoliseksi ammattientarkastajaksi nimettiin Jenny Markelin.

${ }^{2}$ Ensimmäiset kansanravitsemustutkimukset kohdistuivat maalaisväestöön. Sundström S. Untersuchungen über die Ernährung der Landbevölkerung in Finland (1908), Tigerstedt C. Untersuchungen über die Nahrungszuführ des Menschen in ihrer Abhängigkeit von Alter, Geschlecht und Beruf (1916).
} 
työnantaja huolehti lähes aina työntekijöidensä ruokailusta, ja palkka muodostui pääosin työnantajan tarjoamasta täysylläpidosta eli ruoasta ja asunnosta. Teollistumisen myötä palkkauksessa siirryttiin vähitellen rahapalkkaan. (18) Samalla ateriajärjestykseen ja aterioiden koostumukseen alkoi vaikuttaa teollisuudessa noudatettu työaika. (17)

Työpäivät tehtaissa saattoivat olla pitkiä, 12tai 14-tuntisia. Osa tehtaista siirtyi kuitenkin jo vuosisadan vaihteessa 10 -tuntiseen työpäivään. (4) Lainsäädäntö vaikutti tehdastyöläisen ruokailuun sinänsä vähän. Teollisuustyöntekijöiden suojelua koskevassa asetuksessa säädettiin ainoastaan, että lapsen ja nuoren työntekijän oli saatava työpäivän aikana lepotauko. (18) Vuonna 1917 toteutunut laki kahdeksantuntisesta työpäivästä ulotti määräyksen koskemaan kaikkia työntekijöitä: - - - "milloin työ on järjestetty säännöllisesti vaihtuviin, enintään 8 tunnin vuoroihin, on työntekijälle annettava joko vähintään puolen tunnin ruokailuaika tai tilaisuutta syömiseen työvuoron aikana.” Ruokailun osalta laki määräsi vain, että "työhuoneissa, joissa valmistuksen aikana syntyy vahingollisia höyryjä tahi terveydelle vaarallista pölyä, älköön työntekijäin sallittako atrioida tahi muuten mitään nauttia”. (19)

Kansatieteilijä Ilmar Talven mukaan teollisuustyöväestön tyypillisimmiksi aterioiksi muotoutuivat aamukahvi, aamiainen, iltapäivän kahvitunti ja päivällinen kotona kello 18 jälkeen. (20) Osa työntekijöistä kävi työpäivän aikana ruokailemassa kotona tai otti eväitä töihin. Suurten tehtaiden läheisyydessä oli ruokamyyjiä, ja ruokaa saattoi ostaa torien myyntikojuista. Ravintoloiden ja kahviloiden ohella ruokaa sai maksua vastaan yksityiskodeista, mutta niihin työväestöllä ei ollut varaa. $(18,21)$

Suurimmissa kaupungeissa ruokatalous ei maaseudun tapaan enää täysin perustunut omavaraisuuteen, ja elintarvikkeita hankittiin toreilta ja kaupoista. (22) Työläisten kaupunkiasunnoissa ruoanvalmistusmahdollisuudet olivat puutteelliset. Helsingille tyypillinen työläisasunto oli yhden huoneen asunto, hellahuone. Asunnon kaakeliuuni oli sekä huoneen lämmittämiseen että ruoanvalmistukseen. Riittäviä säilytystiloja elintarvikkeille ei ollut. (23) Tampereelle ominainen työläisasunto oli yhteiskeittiöasunto eli huone ja yhteiskäytössä ollut erillinen keittiö. (24)

\section{RATKAISUJA RUOKAILUN ONGELMIIN}

Naispuolisen ammattientarkastajan tehtäviin kuului kiinnittää huomiota työnantajan järjestämiin työoloihin ja opastaa työntekijöitä. Hjeltin ensimmäisiä havaintoja naistyöntekijöiden työoloista olivat työpaikkojen huono ilmanvaihto, kuumuus ja juomaveden kehno laatu. Ruokailutiloissa, joita suurimmat teollisuuslaitokset järjestivät työntekijöille, puutteita oli tilojen riittävyydessä, lämpötilassa ja hygieniatasossa. Heikoin tilanne oli niissä pienissä ompelimoissa, joissa ruokailtiin työtiloissa. (4)

Eräs käytännön ongelma oli ruokataukojen, "päivällislomien", ajoittuminen. Riittävän pitkällä ruokatauolla, mahdollisuudella rauhalliseen ruokailuun ja lepoon, voitiin Hjeltin mielestä osaltaan ehkäistä ammattitautien syntyä. Työnteon ja ruokailun yhteen sovittamiseen liittyviä pulmia Hjelt kuvaa erityisesti ompelijattarien työoloja koskeneessa selvityksessä. Ajan säästämiseksi hän antoi käytännön neuvoksi ruoanvalmistuksen hauduttamalla, "heinissä keittämisen". ${ }^{3}$ Se vastasi hänen mukaansa varakkaimmissa talouksissa käytössä olevia höyrykeittimiä, ”itsekeittoaparaatteja", joita "terveystieteilijät ovat hartaasti puoltaneet ja jotka - - - valmistavat mitä maukkainta ja kaiken ravintoarvon säilyttävää ruokaa.” $(4)^{4}$ Hjeltin aloitteesta Suomen Naisyhdistys laati työläisperheitä varten ohjeen heinälaatikon käytöstä ruoanvalmistuksessa. (23) Työläisnainen -lehdessä päätoimittaja Miina Sillanpää piti niin ikään kyseistä valmistustapaa "tehtaalaisille" sopivana sen edullisuuden ja kätevyyden takia. (25) Kotitaloustyön historiaa ja teknologiaa tutkineen Vuokko Lepistön mukaan työläisperheet omaksuivat "heinissä keittämisen”, mutta täsmällistä tietoa käytön yleisyydestä ei ole. (23) Työnantajia Hjelt kehotti muiden parannusehdotusten ohella hankkimaan eväsruoan lämmittämiseen höyrylämmityskaapin, ajankohdan uutuuden. Sellainen oli Suomessa tuolloin ainoastaan Turun verkatehtaalla, mutta Hjelt tiesi niitä käytettävän esimerkiksi saksalaisilla työpaikoilla. (4)

\footnotetext{
3 Kannellinen puinen laatikko vuorataan heinillä ja keittoastia siirretään kiehumisen jälkeen laatikkoon hautumaan. (23)

${ }^{4}$ Itsekeittoaparaateilla Hjelt tarkoittanee keittokoneita, joita 1890-luvulta lähtien myytiin mm. Helsingissä. (Ks. 23)
} 
Niillä työpaikoilla, joissa naiset tekivät yötyötä, ruokailutiloille oli erityinen tarve. Kyseeseen ei Hjeltin mielestä nimittäin tullut, että naiset kulkisivat keskellä yötä, "puoliyöloman" aikana, koteihinsa ruokailemaan. Ruokailutiloihin liittyi myös eräs naisammattientarkastajille annettu tehtävä, työntekijöiden siveellisten olojen valvominen. Etenkin sahateollisuudessa työskentelevät naiset kokivat mies- ja naistyöntekijöiden yhteiset ruokailutilat epämukaviksi. Sen lisäksi, että tilat olivat ahtaita ja tupakansavuisia, miehet käyttäytyivät niissä yötöiden aikaan naisia kohtaan sopimattomasti. Hjeltin aloitteesta ammattientarkastajat laativat esityksen, jossa työnantajat velvoitettiin järjestämään mies- ja naistyötekijöille erilliset ruokailutilat. (4) Maininta tällaisten tilojen järjestämisestä sisältyi sittemmin, vuonna 1914, annettuun asetukseen. (26)

\section{"AINA EI SAA SYÖDÄ KYLLIKSEEN JA HARVOIN MIELIKSEEN" (5)}

Vuosisadan vaihteessa keskimääräinen suomalainen ruokavalio oli yksinkertainen ja perustui pääosin viljavalmisteisiin, perunaan, maitovalmisteisiin ja pieneen määrään lihaa ja kalaa. (27) Hjeltin kaupunkien ammattityöläisiä koskeneessa tutkimuksessa ravinnon osuus kokonaismenoista oli keskimäärin noin 55 prosenttia, mikä osaltaan viittasi perheiden vähävaraisuuteen. $(6)^{5}$

Vähävaraisuuden Hjelt totesi vaikuttavan epäedullisesti terveydentilaan, mutta siihen vaikutti lisäksi se, ettei työväestön ruokavalinnoissa terveydellisillä seikoilla näyttänyt olevan merkitystä. Työpäivinä nautittiin pääasiassa nopeasti valmistuvaa, ns. kuivaa ruokaa ja juomaa: voileipää ja kahvia tai maitoa tai kaljaa. Päivälliseksi oli yleensä perunoita, pieni määrä lihaa, suolakalaa tai rasvakastiketta. Puuroa syötiin harvoin. (6) Kaikkein suurin ongelma oli kahvi. Siitä oli 1800-luvulla tullut koko kansan nautintoaine, jota aluksi juotiin vain juhlapäivinä, mutta vähitellen sen käyttö oli arkipäiväistynyt (28).

Myös Hjeltin ammattityöväestöä koskenut tutkimus osoitti, että kahvin (sikurin) ja sokerin osuudet ruokamenoissa olivat esimerkiksi perunaan verrattuina suuret. (6) Työläisperheissä

\footnotetext{
5 Ruokamenojen osuus vaihteli 50 prosentista 74 prosenttiin.
}

kahvia ei juotu ainoastaan kotioloissa, vaan sillä korvattiin aterioita töissä. Se oli myös janojuoma, jolla työtilojen kuumuuden aiheuttamaa janoa sammutettiin. Hjeltin kokemuksen mukaan naisia oli vaikea saada käyttämään "vähemmän vaarallisia juoma-aineita", ja hän halusi käynnistää taistelun kahvinjuontia vastaan. Runsas kahvinjuonti oli hänen mielestään syypää naistyöntekijöiden terveysongelmiin, kuten "verenvähyyteen, hermoheikkoisuuteen ja monenmoisiin vatsavammoihin ym., jotka kuluttavat voimia ja lisäävät kuolevaisuusnumeroa heidän keskuudessaan.” (4) Vaikka Hjelt tuo esiin kahvin haitallisuuden, hän toisaalta toteaa kahvin olevan vähävaraisille välttämätön "ravintoaine"6 eikä nautintoaine, sillä "kahvi on ateriaan kuuluva, usein ainoa lämmin keitos köyhän perheen pöydällä.” (6)

\section{KALLIS RUOKA}

Hjelt pohti tapoja, joilla taloudellisesti heikosti toimeentulevien työntekijöiden ruokataloutta olisi mahdollista kohentaa. Eräs keino vähentää ruokakuluja olisi hankintojen keskittäminen ja suurissa erissä ostaminen. Suurostoksiin ja tukkuhintoihin ei yksityishenkilöillä kuitenkaan ollut mahdollisuutta. Tehdastyölle tyypillisten aamuvarhaisten työvuorojen takia he eivät myöskään pystyneet hankkimaan elintarvikkeita edullisesti torilta, suoraan tuottajilta. Vaarana Hjelt näki, että vähävaraisten on tingittävä ruoan laadusta ja turvauduttava huonolaatuisiin, ravintoarvoltaan kehnoihin tai jopa väärennettyihin elintarvikkeisiin. (6)

Toinen tapa vähentää ruokakuluja olisi vaihtaa ruokavalion kalliit ainekset edullisempiin, mutta yhtä ravitseviin ja maukkaisiin ruokaaineisiin. Tässä yhteydessä Hjelt viittaa tanskalaisen lääkärin Mikkel Hindheden näkemyksiin ja hänen suosittelemaansa ruokavalioon. Ajankohdan vallitsevasta ravitsemustieteellisestä suuntauksesta poiketen ${ }^{8}$ Hindhede ehdotti lihan

\footnotetext{
6 Termillä ravintoaine tarkoitettiin 1900-luvun alussa yleensä ruoka-ainetta, elintarviketta.

7 Mikkel Hindhede (1862-1945), lääkäri, ensimmäisen maailmansodan aikainen ravitsemusasiantuntija Tanskan kansallisessa ravitsemustutkimuksen laboratoriossa (Danish National Laboratory for Nutrition Research).

8 Saksalainen Karl von Voit oli asettanut standardiksi $118 \mathrm{~g}$ proteiinia/vrk (48). Se ylitti selvästi Hindheden arvion proteiinin tarpeesta.
} 
- merkittävänä pidetyn eläinproteiinin lähteen, mutta kalliin raaka-aineen - vähentämistä ruokavaliossa ja sen korvaamista edullisilla kasvikunnan tuotteilla. Tavoitteena oli ruokavalio, jonka Hjelt määritteli termillä "vanha talonpoikaisruoka". Siihen kuului "leipää, jauhoja, ryynejä, maitoa, voita ja muita rasva-aineita, juustoa, herneitä, kaalia, juuriksia, marjoja, rabarberia ja muita kyökkikasveja sekä pieni määrä munia, kalaa ja lihaa.” (6) 1900-luvun ravitsemusta ja yhteiskuntapolitiikkaa tarkastellut Mikko Jauho toteaa suosituksen yksinkertaiseen maalaisruokaan siirtymisestä olleen yleinen tuon ajankohdan kirjoituksissa. Kyse saattoi olla maaseutuelämän ihannoimisesta kaupunkielämään verrattuna, ja siten ilmiö heijastelisi vanhaa, ihanteellista kansankäsitystä. Taustalla on myös voinut olla kritiikki alempien sosiaaliluokkia kohtaan; kaupunkityöläisten katsottiin elävän yli varojensa heidän tavoitellessaan yläluokan ruoankäyttöä. (29)

Hindheden näkemykset herättivät Suomessa kiinnostusta siinä määrin, että hänen teoksensa "Ravintomme uudistus: elä terveellisesti! Elä voimakkaana! Elä halvalla!” suomennettiin 1907, pian ilmestymisen jälkeen. ${ }^{9}$ Uutuuskirjaa esiteltiin muun muassa Työläisnainen (30) ja Työmies - (31) lehdissä. Käytettävissä olevat kirjastotiedot osoittavat, että sekä "Ravintomme uudistus" että Hindheden toinen kirja, "Säästötaloudellinen keittokirja: käytännöllinen ravinto: yli 200 terveellistä ja helppohintaista ruokalajia: reseptejä joka päivää varten 8 viikossa” (1908), hankittiin tuolloin Helsingin työväenyhdistyksen kirjastoon.

Lehtien kirjaesittelyissä Hindheden ruokavaliosuosituksen ei todettu olevan erityisen merkittävä, mutta "kyllin suuri tehdäkseen sosiaalisessakin suhteessa niin kireäksi käyneen ravintokysymyksen helpommin ratkaistavaksi." (32) Kirjoja esiteltiin muun muassa Suomen Terveydenhoitolehdessä, ja siinä ruokavalion nähtiin muistuttavan tyypillistä suomalaista ruokavaliota, "koska Suomen kansa ei ollut mikään lihansyöjä kansa.”(33-34, 35) Tätä osoitti myös Hjeltin ammattityöväestöä koskenut tutkimus, jonka mukaan lihan osuus ruokavaliossa oli vä-

\footnotetext{
9 Esipuheen suomenkieliseen kirjaan teki terveysopin professori Taavetti Laitinen.
}

häinen. Eläinkunnan tuotteiden osuus ruokamenoista oli kuitenkin suuri, keskimäärin 51 prosenttia. (6)

\section{EROON TIETÄMÄTTÖMYYDESTÄ}

Työläisnaisten työhyvinvoinnin, heidän "kivulloisuutensa", taustalla eivät Hjeltin mielestä olleet yksinomaan työtehtävät, työolot tai taloudellinen tilanne, vaan siihen vaikuttivat työläisnaisten vähäiset tiedot terveyteen vaikuttavista elintapatekijöistä. (4)

Hjeltin näkemys sopii hyvin tuolloiseen käsitykseen ns. tavallisen kansan tietämättömyydestä. Hygienia, ennaltaehkäisevä terveydenhoito-oppi, oli 1800-luvun lopulla vallitseva lääketieteessä. Sen toiminta-ajatus oli väestön, etenkin kaupunkiväestön, valistaminen terveellisen elämän periaatteista. Vastuun yksilökohtaiseen hygieniaan sisältyvistä asioista katsottiin kuuluvan perheille, mutta perheet tarvitsivat tietoa ja tukea. Valistukseen, oikeiksi katsottujen elintapojen omaksumiseen, sisältyi myös ravinto. $(29,36)$

Teollistumisen myötä tiedon leviämistavat muuttuivat. Aiemmin toimintatavat opittiin edellisiltä sukupolvilta tai jäljittelemällä ylempiä sosiaaliluokkia. Nyt uutuuksille ja uudelle tiedolle oli muita väyliä, ja tiedon sisällöstä vastasivat koulutetut ammattilaiset, kuten lääkärit ja kansakoulunopettajat. (36) Neuvontajärjestöillä, keittoja opaskirjoilla ${ }^{10}$, talouskouluilla ja kotitalousopetuksella (37), oli keskeinen asema. Kansannaisten sivistäminen ja opetuksen tarjoaminen kuuluivat esimerkiksi Martta-Yhdistyksen tavoitteisiin. (38) 1800-luvun lopulla alkoi myös kansan- ja työväenopistojen aikuisväestölle suunnattu vapaa kansanvalistustoiminta. (39) 1920luvun uusia tiedonväyliä olivat perheenemännille suunnattu Kotiliesi -lehti ja vuosikymmenen lopulla perustettu Oy Suomen Yleisradio.

Naisten neuvonta, terveys- ja moraalikasvatus, kuuluivat myös naisammattientarkastajan työtehtäviin, ja toimintakertomusten mukaan Hjelt antoi vuosittain lukuisia "ruokajärjestystä koskevia" ja "ruokahoidollisia" neuvoja työntekijöille. Niiden aihepiirejä ei kertomuksissa mainita, mutta osa näyttää liittyneen kahviin ja sen korvaamiseen ruokavaliossa. Naisten pinttyneiden ruokatottumusten muuttaminen ei kuiten-

\footnotetext{
${ }^{10}$ Esim. Borg R. Tehtaannaisen keittokirja (1913).
} 
kaan ollut helppoa. Parhain tapa saada muutosta aikaan oli Hjeltin kokemuksen mukaan henkilökohtainen neuvonta, sillä "tehtaan seinille naulatut yleiset terveydenhoidolliset neuvot eivät voi koskaan korvata persoonallista lähestymistä ja sydämellistä harrastusta työntekijän terveyteen ja hyvinvointiin. Häneen vaikuttaa aina ystävällinen sana." (4)

Valistamiseen Hjelt pyrki myös kannustamalla työnantajia ruoanvalmistuskurssien järjestämiseen. Siten tieto esimerkiksi "ravintoaineista" ja niiden merkityksestä leviäisi työläisnaisten keskuuteen "ei ainoastaan keskustelemalla kodeissa vaan myöskin yhteisen ruoan kautta". Kurssit sopivat Hjeltin mielestä vuorotyötä tekeville sekä työläisperheiden tytöille, jotka siten olisivat tietoisia ravintoasioista tullessaan aikanaan tehdastöihin. Malli teollisuuslaitoksissa järjestettäville kursseille näyttää tulleen Ruotsista. Siellä niitä nimitettiin "kiertäviksi koulukeittiöiksi”. Suomessa kurssien järjestämiseen osallistui muun muassa Martta-Yhdistys. (4)

Tärkein kurssilla käsiteltävä aihe oli Hjeltin mielestä tehdastyöväen eväät ja niiden valmistaminen, sillä nykyisellään eväsruoka oli "mitä epäsoveliainta, epäterveellisintä ja ravitsemattominta” sekä kallista. Lisäksi tällaisessa ruokavaliossa päivän ainoa lämmin ateria ajoittui iltamyöhään. Kahvin ja leivän sijasta evääksi olisi valmistettava lämmintä ruokaa, ja tähän tarvittiin opastusta. Lämmin eväsruoka olisi mahdollista kuljettaa työpaikalle "keittovasuissa", joita Hjelt tiesi Ruotsissa käytettävän. (4) Kyseessä lienee ollut ns. kannettava keittokone, jota työläisnaisille esiteltiin myös suomalaislehdissä. (40) Se ei kuitenkaan yleistynyt, sillä monelle perheelle lähes ompelukoneen hintainen laite oli liian kallis. (23)

Vuonna 1908 Hjelt totesi kursseja pidetyn useilla tehdaspaikkakunnilla, ja kokemukset olivat myönteisiä. (4) Vaatimattomankin talouden pitoon tarvittiin Hjeltin mukaan tietoja ja taitoja, ja mikäli kansakoululaitos ei asiaa pysty järjestämään, hän esitti "kansanhygieenisiä ja kansantaloudellisia etuja silmällä pitäen" kotineuvojattarien toimien perustamista kuntiin. Tiedoilla ja taidoilla saattoi hänen mukaansa olla jopa suurempi merkitys kuin perheiden käytettävissä olevilla varoilla tai ruoanvalmistukseen käytettävissä olevalla ajalla. (6)
Riitta Oittinen on tutkinut Työläisnainen -lehden 1900-luvun alun terveysaiheisia artikkeleita ja sitä, miten lehdessä otettiin kantaa kansalaisten valistamiseen ja työväestön ruokakysymykseen. Ruoanvalmistuskursseihin suhtauduttiin lukijoiden keskuudessa osin penseästi. Toisin kuin Hjelt totesi, puutteellisten ruoanvalmistustaitojen syynä ei niiden mukaan ollut ensisijaisesti taito, vaan työläisperheiden taloustilanne: rahaa ruokaan ei ollut. (41)

\section{UUDEN AJAN KEITTIÖT}

Jo 1860-luvulla Helsingissä oli työväestölle suunnattuja keittoloita, mutta Helsingin työkoti- ja työmaja -yhdistyksen 1893 (42) perustama höyrykeittiö oli ensimmäinen suurten joukkojen ruokala. Lämpimän ruoan järjestäminen työväestölle katsottiin tarpeelliseksi sekä työtehon että terveyden kannalta, mutta se oli myös taistelua raittiuden puolesta - vaihtoehto kapakoille. (23)

Johtosäännön mukaan naisammattientarkastajan tehtäviin kuului "ruoanpitolaitoksien" edistäminen, ja omalta osaltaan tarkastajat pyrkivät jouduttamaan muun muassa tehdasruokaloiden perustamista. (21) Ruokalat osoittautuivat kuitenkin kannattamattomiksi. Hjeltille esitettiin syyksi, ettei niiden tarjonta ollut mieluista, "kun [ruokailijat] eivät saaneet imelälientä ${ }^{11}$ ja pannukakkua." Syynä tehdasruokaloiden vieroksumiseen saattoi myös olla ruoan kalleus. $(4,18)$

Eräs keino parantaa vähävaraisten taloudellista tilaa oli Hjeltin mielestä yhteis- ja osuuskeittiötoiminta, joka oli jo virinnyt Suomessa. (6) Osuuskeittiöt saattoivat olla muutamien tai muutamien kymmenien perheiden sopimus ruoanvalmistuksen järjestämisestä, ts. ruoanvalmistuksessa siirryttiin yksityiskeittiöistä yhteiskeittiöihin. Vuokko Lepistön mukaan toimintaan osallistui sekä työväen- että keskiluokan perheitä. Työläisnainen -lehdessä osuuskeittiöitä kannatettiin, sillä ne päästivät perheenäidit "paistinpannuorjuudesta”. (23) Tuona ajankohtana alettiin myös erityisesti naisjärjestöissä keskustella kotitalouksien tehtävästä yleensä, ja siitä, miten ja kenen toimesta kotia ja perheiden ruokataloutta tuli hoitaa. $(23,29,38,43)$

11 Imeläliemi tarkoittaa ilmeisesti rusinakeittoa. 
Erityisen myönteisenä Hjelt näki sen, että yksityiset olivat enenevässä määrin perustaneet tehtaiden läheisyyteen kansankeittiöitä, ravintoloita, joissa tarjottiin kohtuuhintaista ruokaa. Kilpailu oli parantanut ruoan laatua, mutta tarjonnan monipuolistamisessa ja ruokaloiden viihtyisyydessä mallia olisi otettava tanskalaisista ja saksalaisista työväenruokaloista. (4) Parhaimmillaan kansankeittiöissä on Hjeltin mukaan mahdollisuus kiinnittää huomiota ajanmukaiseen ravitsemustietoon, ruoka-aineiden valintaan ja ruoanvalmistukseen eli seikkoihin, joihin vähävaraisella väestönosalla ei ole yleensä aikaa eikä kykyä. Kansankeittiötoiminnalle oli kuitenkin laadittava ohjeet, ja niiden julkinen valvonta oli järjestettävä. $(6,23)$

Kaupunkeihin ja tehdaspaikkakunnille Hjelt esitti perustettavan myös keittiöitä, joista ruokaa tietyin periaattein toimitettaisiin koteihin ja työpaikoille. Vähävaraisten perheiden olisi tälläkin tavoin mahdollisuus saada aiempaa "terveellisempää12, vaihtelevampaa ja ravitsevampaa" ruokaa, mikä edistäisi kansanterveyttä. Hjelt arveli, että lämpimän ruoan kotiinkuljetus saattaa tulevaisuudessa olla eräs yhteiskunnan tärkeimpiä toimintamuotoja. (4)

Ensimmäisen maailmansodan (1914-1918) aiheuttaman elintarvikepulan ja hintojen nousun takia monet yksityiset kansankeittiöt joutuivat luopumaan toiminnastaan 1910-luvun lopulla. Vaihtoehdoksi niille Hjelt suositteli osuuskeittiömallia, jossa työntekijät olivat osakkaina tehdasruokalassa ja vastasivat toiminnasta. (4) Ammattientarkastajan edistämät tehdasruokalat alkoivat puolestaan yleistyä vasta itsenäistymisen jälkeen. 1920-luvulla tehdyn selvityksen mukaan noin joka seitsemännessä teollisuuslaitoksessa oli tuolloin tehdasruokala. (21)

\section{RAVITSEMUS OSANA TYÖSUOJELUNÄYTTELŸ̈'13}

Vera Hjeltin työ jatkui ammattientarkastajan tehtävän jälkeen päätoimisena työsuojelunäyttelyn johtajana vuodesta 1917. Teollisuushallituksen alaisena toimineen, koko väestölle suunnatun

\footnotetext{
${ }^{12}$ Terveellisellä Hjelt tarkoittanee ns. yksinkertaista talonpoikaisruokaa.

${ }^{13}$ Näyttelystä on käytetty eri yhteyksissä myös nimiä Työväensuojelu(s)- ja huoltonäyttely, Sosiaalimuseo, Yhteiskunnallinen museo, Työsuojelunäyttely - työsuojelun tietoja opastuskeskus.
}

näyttelyn tavoitteena oli herättää kiinnostus työsuojelukysymyksiin sekä tutustuttaa työnantajat ja työntekijät ajanmukaisiin suojalaitteisiin. Näyttelyssä oli sen alusta lähtien myös ihmisen ravitsemusta, ravintofysiologiaa ja elintarvikkeita käsittelevä osasto. (44-46)

Ensimmäinen maailmansota lisäsi tarvetta luonnontuotteiden ja korvikkeiden käyttöön, ja niitä esittelevä kokoelma oli näyttelyssä esillä 1910-luvun lopulta lähtien. Tuossa, alun perin sota-ajan elintarvikehuoltoa varten perustetun Valtion kotitaloustoimikunnan (1917-1923) rakentamassa kokoelmassa oli kahvin ja leipäjauhojen korvikkeita, olki- ja muita hätäleipiä sekä kuivattuja ja jauhettuja luonnonkasvinäytteitä yhteensä parinsadan nimikkeen verran. $(7,47)$

1920-luvun lopulta lähtien työsuojelunäyttely valisti ruoka-aineiden koostumuksesta suhteessa niiden hintaan - "Osta ravintosi harkiten. Tärkein on ravintoarvo eikä paljous." Osastolla olleessa "ravintopöydäksi" kutsutussa kokoelmassa oli lähes sata elintarvikenäytettä, joista kukin sisälsi $500 \mathrm{kcal}$. Samalla esiteltiin aterioiden, kuten aamiaisen, suositeltavaa koostumusta ja ravintoaineiden tarvetta eri ikäryhmissä ja työtehtävissä. Kokoelma oli alkuaan rakennettu 1926 Suomen ensimmäisille ravinto- ja nautintoainemessuille. Sen oli suunnitellut Robert Tigerstedtin poika, Helsingin yliopiston fysiologian professori Carl Tigerstedt. Kuten kyseisenä ajankohtana muuallakin (48), myös Suomessa väestöä opastettiin tuolloin tekemään viisaita ostopäätöksiä ottamalla hintojen lisäksi huomioon ruoka-aineiden ravitsemuksellinen laatu, niiden ravintoarvo. ${ }^{14}$ Samalla pyrittiin vähentämään elintarvikkeiden hintoihin ja koostumukseen liittyneitä väärinkäsityksiä. (49) Kokoelmasta tuli suosittu, ja sen kiinnostavuutta on arveltu lisänneen ensimmäiset suomalaista alkuperää olleet, luonnollisilta näyttäneet synteettiset ruokamallit. $(45,46,50)$ Näitä ruokamalleja oli näyttelyssä esillä vielä 1960-luvun lopulla. (46)

Ruoka- ja ravintoaineita koskevaa valistusmateriaalia oli monessa muodossa: kuvina,

\footnotetext{
${ }^{14}$ Esim. von Wendt G. Ravintomme taloudellinen arvo. Miksi syömme? Paljonko ravintoa tarvitsemme päivittäin? Tavallisimpien ruoka-aineittemme ravintoarvo ja hintasuhteet (1916), Graae I, Tigerstedt C. Kalliin ajan ruokatalousohjeita. Erikoisesti huomioon ottaen tärkeimpien ruoka-aineittemme ravintoarvon (1916), Tigerstedt C. Halpahintainen ruoka (1924).
} 
piirroksina, dioina ja opetuselokuvina. (44-46) 1930-luvun alussa tuberkuloosin ehkäisyä käsittelevällä osastolla esiteltiin ns. Oslo-aamiainen ${ }^{15}$, joka oli silloisen ravitsemustietämyksen perusteella suunniteltu paras mahdollinen aamiaiskokonaisuus koululaisille. Norjalaisen koululääkärin Carl Schiøtzin laatima vaihtoehto koululounaalle tuli tunnetuksi muun muassa Pohjoismaissa. (51, 52)

Vera Hjeltin vaikutusta lienee se, että myöhemmin 1930-luvulla, Hjeltin jo luovuttua työsuojelunäyttelyn johtajan tehtävästä, ravitsemusosastolla esiteltiin eri väestöryhmille, kuten rautatieläiselle, työmiehelle, virkanaiselle ja koululaiselle suositeltavia eväsruokia. (7) Tuolloin valmistui myös Hjeltin ideoima ns. kiertävä näyttely, jota vuosina 1932-1938 esiteltiin maaseutupaikkakunnilla. Kiertävään näyttelyyn sisältyi pieni osa ihmisen ravitsemusta käsittelevästä osastosta. (7, 45, 46) Ruoka-aineiden vitamiinipitoisuuksia koskevan tutkimustiedon lisäännyttyä Suomessa 1930-luvun lopulla (16) näyttelyaineistoa täydennettiin niiltä osin. Ravintofysiologiaa esittelevää osiota olivat 1950luvulla uusimassa alan suomalaiset asiantuntijat. Yhteistyötä ravintoon liittyvissä kysymyksissä tehtiin järjestöjen ja ruoka-alan toimijoiden, kuten Leipätoimikunnan, Maito ja Terveys -yhdistyksen sekä Margariinitehtaiden tiedotuskeskuksen kanssa. Vuonna 1963 toteutettiin Mannerheimin Lastensuojeluliiton kanssa näyttely "Syötkö terveesti??. (46)

Työsuojeluhallinnon uudistuksen myötä näyttelytoiminta päättyi Helsingissä syksyllä 1973. Nykyisin Tampereella toimivassa Työsuojelunäyttelyssä ruoka ja ihmisen ravitsemus eivät ole erityisesti esillä. Tiloissa nähtävillä oleva ruoansulatusta esittelevä iso korkokuva on osa suurta kiinnostusta herättänyttä Ihminen-näyttelyä, joka toteutettiin 1960 yhteistyössä saksalaisen Hygiene-Museum (Dresden) kanssa (46).

\section{TYÖAIKAISEN RUOKAILUN KEHITTÄJÄ}

Ensimmäisenä viranhaltijana Vera Hjelt loi perustan sittemmin useita vuosikymmeniä jatkuneelle naispuolisten ammattientarkastajien työlle. Työsuojelullisten tehtävien ohella hän teki konkreet-

\footnotetext{
${ }^{15}$ Oslo-aamiainen sisälsi maitoa, tummaa leipää ja näkkileipää, margariinia, juustoa/makkaraa, omenan ja porkkanan/appelsiinin.
}

tisia parannusehdotuksia työaikaisen ruokailun järjestämiseksi ja pyrki ohjaamaan työväestöä ravintoon liittyvissä kysymyksissä. Hjelt oli kiinnostunut valistustyöstä, ja hänen tavoitteenaan oli etenkin naisten työolojen parantaminen. Hänellä ei ollut muodollista, ravintoa ja ihmisen ravitsemusta koskevaa erityisasiantuntemusta eikä alan koulutusta. Hjeltin vahvuus oli niiden epäkohtien hyvä tuntemus, jotka nopeasti kehittynyt teollisuus Suomessa oli synnyttänyt.

1900-luvun alussa ravitsemustiede oli vaiheessa, jossa tunnettiin proteiinien, hiilihydraattien ja rasvojen merkitys, ja eräät kivennäisaineet tiedettiin elimistölle välttämättömiksi. Lisäksi oltiin perillä siitä, että ravinnon eräitä orgaanisia yhdisteitä tarvitaan ihmisen kasvuun ja aineenvaihduntaan. Työväestön työkyky ja työteho olivat ajankohtaisia tutkimusaiheita niin Suomessa kuin muuallakin. (16) Oman leimansa vuosisadan alun ravitsemuskysymyksiin, tutkimukseen ja väestön neuvontaan antoi etenkin vähävaraisen kaupunkiväestön elinoloja heikentänyt ensimmäinen maailmansota. (53-55)

Vera Hjelt toimi ajankohtana, jolloin työväestöön suunnattu valistustyö voimistui ja neuvonta ammattimaistui. Hänellä oli yhteyksiä neuvontajärjestöihin, ja Hjelt oli esimerkiksi MarttaYhdistyksen perustamisen aloitteentekijöitä. (2) Vuorovaikutus suomalaisten ravitsemuksen asiantuntijoiden kanssa välittyy tässä käytetyn aineiston osalta ainoastaan työsuojelunäyttelyä koskevista tiedoista. Merkittävä innoituksen ja tiedon lähde sekä ammattientarkastajan tehtävälle että näyttelytoiminnalle olivat hänen ulkomaille suuntautuneet opintomatkansa. (4) Ideoita työsuojelunäyttelyn ravitsemusta käsittelevän osaston aihepiireihin ja toteutukseen Hjelt näyttää saaneen etenkin Saksasta. Eri vuosikymmenten painotuksineen työsuojelunäyttely on erityinen osa suomalaisen ravitsemusvalistuksen historiaa. Ennalta ehkäisevänä toimintana sen merkityksen arviointi on kuitenkin vaikeaa.

Työaikaisen ruokailun kehittäminen osana työsuojelua on ollut tärkeä vaihe rakennettaessa nykyäänkin terveyden ja hyvinvoinnin kannalta keskeisenä pidettyä työpaikkaruokailua Suomessa. Sadan vuoden aikana työskentelyolot esimerkiksi teollisuudessa ovat olennaisesti muuttuneet. Perustaltaan työaikaiseen ruokailuun kohdistuvat tutkimuskysymykset ovat kuitenkin osin samankaltaisia ja liittyvät työaikaisen ruokailun 
järjestämisperiaatteisiin, työntekijöiden osallistumismahdollisuuksiin sekä työaikaisen ruokailun merkitykseen hyvinvoinnille. Hjeltin sadan vuoden takainen arvio ruokapalvelujen tulevaisuuden näkymistä, kuten lämpimän ruoan kotiinkuljetuksesta, on osa tätä päivää.

Ensimmäiset työpaikkaruokailua koskevat ravitsemussuositukset Työterveyslaitos antoi 1971 (56). Nykytiedon mukaan henkilöstöravintolassa ruokailulla on myönteisiä vaikutuksia työntekijöiden ruokavalion ravitsemukselliseen laatuun (57). Ruokapalvelujen kehittäminen ravitsemuksellisen laadun osalta on yksi nykyisen ravitsemuspolitiikan kulmakiviä. Tehdastyöväen työaikaisesta ruokailusta käynnistynyt ja muille toimialoille ja palvelusektoreille laajentunut ruokapalvelutoiminta on olennainen osa tämän päivän suomalaista ruokakulttuuria.

Rautavirta, K. Factory inspector Vera Hjelt - nutrition counselling and occupational safety. Sosiaalilääketieteellinen aikakauslehti- Journal of Social Medicine 201 8: 55: 60-70

At the end of the 1800s, industrial workers were the first large population group in Finland whose workplace was transferred from home to factories and workshops. This meant, among other things, changes in traditional eating habits. Vera Hjelt was appointed as the first female factory inspector in Finland. This article deals with her actions concerning nutritional issues. In addition to issues in occupational safety at factories and workshops, she made efforts to improve workers' welfare in general, like influencing their eating patterns and promoting the availability of canteens at worksites. Hjelt was interested in counselling and she aimed to improve the work- ing conditions of women especially. Her practical way to demonstrate nutritional issues was visible also at the Exhibition of Occupational Safety she founded in 1909. Vera Hjelt's career in the field of occupational safety lasted nearly thirty years. That time period, her work, is an important stage in the Finnish history of nutrition counselling as well. Vera Hjelt can also be considered as a pioneer in promoting worksite food services in Finland.

Keywords: Vera Hjelt, nutrition counselling, worksite canteen, food culture, workers

Saapunut 17.10.2017

Hyväksytty 3.1.2018

\section{LÄHTEET}

1 Hjelt-Cajanus E. Vera Hjelt: uranuurtaja. Turku: Aura; 1948.

2 Korppi-Tommola A. Vera Hjelt (1857-1947) ammattientarkastaja, veistonopettaja, kansanedustaja, Sosiaalimuseon perustaja. Kansallisbiografia-verkkojulkaisu. Studia Biographica 4. Helsinki: Suomalaisen Kirjallisuuden Seura; 1997. Viitattu 12.10.2017.

3 Vuolle-Selki T. Vera Hjelt: työväensuojelija. Helsinki: Book on demand cop; 2013.

4 Vera Hjeltin laatimat vuosien 19031915 toimintaa koskevat kertomukset (Naisammattientarkastajan kertomukset). Kertomukset on julkaistu Suomen teollisuushallituksen tiedonantoja -sarjassa, numerot 35 (1904), 37 (1905), 40 (1906), 44 (1907), 46 (1909), 48 (1910), 52 (1910), 54 (1911), 56 (1913), 59 (1914), 62 (1915 ja 64 (1916). Helsinki: Päivälehden kirjapaino/Senaatin kirjapaino.
5 Hjelt V. Tutkimus koskeva ompelijattaren ammattioloja Suomessa. Suomen virallinen työtilasto VI. Helsinki: Keisarillisen senaatin kirjapaino; 1908.

6 Hjelt V. Ammattityöläisten toimeentuloehdot Suomessa vv. 1908-1909. Suomen yleinen työtilasto XIII. Helsinki: Keisarillisen senaatin kirjapaino; 1912.

7 STM, sosiaali- ja terveysministeriö, työväensuojeluja huoltonäyttelyn (sosiaalimuseon) arkisto, 441:13. Helsinki: Kansallisarkisto.

8 Virrankoski P. Suomen historia: maa ja kansa kautta aikojen. Helsinki: Suomalaisen Kirjallisuuden Seura; 2012.

9 Haapala P. Kun kaikki alkoi liikkua. Kirjassa: Häggman K, Haapala P. (toim.) Suomalaisen arjen historia 3. Modernin Suomen synty. Porvoo: Weilin \& Göös, Porvoo; 2007, 47-63. 
10 Haapala P. Tehtaan valossa. Teollistuminen ja työväestön muodostuminen Tampereella 18201920. Tampere: Vastapaino ja Helsinki: Suomen Historiallinen Seura; 1986.

11 Asetus teollisuusammateissa olevain työntekijäin suojelemisesta 15.4.1889, 18/1889.

12 Forelius S. Valistuksen voimalla työtapaturmia vastaan. Työväensuojelu- ja huoltonäyttely teollisuustyöntekijöiden valistajana. Tampere: Tampereen yliopisto, sosiaalipolitiikan ja sosiaalityön laitos; 2003.

13 Päätös koskeva johtosääntöä naispuoliselle apulais-ammattientarkastajalle Suomessa 19.3.1903, 13/1903.

14 Gripenberg A. Naispuolisia ammatintarkastajia. Koti ja yhteiskunta 1901;1:6-9.

15 Tigerstedt R. Om undersökning af finske arbetares föda. Fin Lakaresallsk Handl 1903; 45:493-501.

16 Ahlström A, Rautavirta K. Fysiologit Robert ja Carl Tigerstedt Suomen kansanravitsemuksen edistäjinä. Hippokrates 2013;13:49-66.

17 Talve I. Suomen kansanomainen ruokatalous. Turku: Turun yliopisto, kansatieteen laitos; 1973.

18 Tarasti K. Elämänluukku. Valtion ravitsemiskeskus 1948-1988. Helsinki: Valtion ravitsemiskeskus; 1987.

19 Laki kahdeksan tunnin työajasta 27.11.1917, 103/1917.

20 Talve I. Teollisuustyöväen työ- ja elämänoloista ennen I maailmansotaa. Kirjassa: Hako M. (toim.) Työväenliike kulttuuritekijänä. Helsinki: Kirjayhtymä; 1969.

21 Tainio R, Tarasti K. Suomalaisen työpaikkaruokailun kehitys. Kirjassa: Hasunen K, Helminen P, Lusa R ym. (toim.) Yksin vai yhdessä? Työpaikkaruokailu murrosvaiheessa. Helsinki: Työterveyslaitos; 1995, 9-18.

22 Räsänen M. Ruoka ja juoma sosiokulttuurisena kuvastimena. Ruokakulttuurin tutkimuksen ongelmia, metodeja ja kehityksen suuntaviivoja. Jyväskylä: Jyväskylän yliopisto, etnologian laitos; 1980.

23 Lepistö V. Joko Teillä on primuskeitin? Kotitalousteknologian saatavuus ja tarjonta Helsingissä 1800-luvun puolivälistä 1910-luvun lopulle. Helsinki: Suomen Historiallinen Seura; 1994.

24 Laine L, Markkola P, Hentilä M. Tuntematon työläisnainen. Tampere: Vastapaino; 1989.

25 Sillanpää M. Keittäkää heinissä. Työläisnainen 1907;33:264-265.

26 Asetus ammattivaaralta suojelemisesta 4.4.1914, $10 / 1914$

27 Roine P. Suomen kansan ravinto. Kirjassa: Linkomies E. (toim.) Oma maa. Tietokirja Suomen kodeille. Helmikuu. Porvoo: WSOY; 1958,179190.

28 Saarinen T. Pannu kuumana. Suomalaisia kahvihetkiä. Helsinki: Suomalaisen Kirjallisuuden Seura; 2011.
29 Jauho M. Työväenravitsemuskysymys. Ravitsemus ja yhteiskuntapolitiikka Suomessa 1900-luvun alkupuoliskolla. Kirjassa Helén I, Jauho M. (toim.) Kansalaisuus ja kansanterveys. Helsinki: Gaudeamus; 2003,146-174.

30 Kirjallisuutta. Työläisnainen 12.12.1907, 409.

31 Werner Söderström Osakeyhtiön kirjauutuuksia. Työmies 27.11.1907, 5.

32 Werner Söderström Osakeyhtiön viime viikkojen uutuudet. Työmies 9.12.1907, 3 .

33 ReijoWaara K. M. Hindhede. Ravintomme uudistus. Kirja-arvostelu. Suomen Terveydenhoitolehti 1908;1:13-14.

34 ReijoWaara, K. M. Hindhede: Säästötaloudellinen keittokirja. Kirja-arvostelu. Suomen Terveydenhoito-lehti 1908;7-8:123-124.

35 Ravintomme uudistus. Työmies 10.4.1908, 5.

36 Harjula M. Terveyden jäljillä - suomalainen terveyspolitiikka 1900-luvulla. Tampere: Tampere University Press; 2007.

37 Sysiharju A-L. Naisasian tytär - muuttuvien kotien tuki. Vuosisata kotitalousopettajien koulutusta Helsingissä. Helsinki: Helsingin yliopisto, opettajankoulutuslaitos; 1995.

38 Ollila A. Suomen kotien päivä valkenee... Marttajärjestö suomalaisessa yhteiskunnassa vuoteen 1939. Helsinki: Suomen Historiallinen Seura; 1993.

39 Nyström S. Oodi sivistykselle. Helsingin työväenopisto 100 vuotta. Helsinki: Minerva Kustannus Oy; 2014.

40 Schybergson J. Tehkäämme ruuan valmistus helpommaksi. Emäntälehti 1906;7-8:114-115.

41 Oittinen R. "Leipää, suojaa ja valoa”. Työläisnainen-lehti työkansan terveyden puolestapuhujana. Kirjassa Helén I, Jauho M. (toim.) Kansalaisuus ja kansanterveys. Helsinki: Gaudeamus; 2003, 175-195.

42 Helsingin työkoti ja yömaja. Turun Lehti 4.3.1893.

43 Heinonen V. Talonpoikainen etiikka ja kulutuksen henki: kotitalousneuvonnasta kuluttajapolitiikkaan 1900-luvun Suomessa. Helsinki: Suomen Historiallinen Seura; 1998.

44 Hjelt V. Kymmenvuotiskertomus työväensuojelusja huoltonäyttelyn toiminnasta vuosina 19101919. Helsinki; 1920.

45 Hjelt V. Sosialimuseo. 20-vuotiskertomus: työväensuojelu- ja huoltonäyttely 1909-1929. Helsinki; 1930.

46 Saari M. Työsuojelunäyttely 60-vuotias (Työväensuojelu- ja huoltonäyttely). Sosiaalinen Aikakauskirja, eripainos. Helsinki: Valtion painatuskeskus; 1969.

47 Yhteiskunnallinen museo: valtion työväensuojeluja huoltonäyttely. Selostava luettelo. 1926.

48 Milles D. Working Capacity and Calorie Consumption: The History of Rational Physical Economy. Kirjassa: Kamminga H, Cunningham A. (toim.) The Science and Culture of Nutrition, 1840-1940. Amsterdam: Rodopi; 1995, 75-96. 
49 Rautavirta K, Ahlström A. Cheap and Nutritious Domestic food for All: the First Food Fair in Finland, 1926. Kirjassa: Nelleke T, Scholliers P. (toim.) A Taste of Progress. Farnham: Ashgate; 2015, 91-109.

50 Björklund M. Työväensuojelu- ja huoltonäyttely 50-vuotias. Sosiaalinen Aikakauskirja, eripainos. Helsinki: Valtion painatuskeskus; 1960.

51 Lungø IJ. The Oslo Breakfast - An Optimal Diet in One Meal. Ethnologia Scandinavica 1998;28:62-75.

52 Andresen A, Elbakken KT. From poor law society to the welfare state: school meals in Norway 1890s-1950s. J Epidemiol Community Health 2007;61:374-377. https://doi.org/10.1136/jech.2006.048132

53 Rantatupa H. Elintarvikehuolto ja -säännöstely Suomessa vuosina 1914-1921. Studia Historica Jyväskyläensia 17. Jyväskylä: Jyväskylän yliopisto; 1979.
54 Rautavirta K. Petusta pitsaan. Ruokahuollon järjestelyt kriisiaikojen Suomessa. Helsinki: Helsingin yliopisto, maatalous-metsätieteellinen tiedekunta; 2010.

55 Nyström S. Poikkeusajan elämänkerta: Helsinki ja helsinkiläiset maailmansodassa 1914-1918. Helsinki: Helsingin yliopisto, humanistinen tiedekunta; 2014.

56 Laakkonen E. Toimipaikkaruokailu Suomessa vuonna 1970. Työterveyslaitoksen tutkimuksia. Helsinki: Työterveyslaitos; 1972.

57 Raulio S. Lunch eating patterns during working hour and their social and work-related determinants. Study of Finnish employees. Helsinki: Terveyden ja hyvinvoinnin laitos; 2011.

Kaija Rautavirta

Elintarviketieteiden tohtori, yliopistonlehtori

Helsingin yliopisto

Kasvatustieteellinen tiedekunta 